\title{
Congenital Peribronchial Myofibroblastic Tumor: A Case Report and Review of the Literature
}

\author{
Arbil Açıkalın', Derya Gümürdülü', Emine Bağır', Gülfiliz Gönlüşen'1, Serdar İskit² \\ 'Department of Pathology, Çukurova University Medical Faculty, Adana, Turkey \\ ${ }^{2}$ Department of Pediatric Surgery, Çukurova University Medical Faculty, Adana, Turkey
}

\begin{abstract}
Background: Congenital peribronchial myofibroblastic tumor is a rare, solid mesenchymal tumor of the neonate, usually associated with non-immune hydrops fetalis.

Case Report: We present a case of congenital peribronchial myofibroblastic tumor, in whom a right lung mass was detected in intrauterine life. 12 days after delivery by caesarean section, right lobectomy was performed. The tumor was limited to the lung, and was composed of spindle cells, proliferating around a bronchial unit. Central necrosis and 4-5 mitoses per 10 high power fields were present. The patient is well 26 months after surgery.

Conclusion: We report this rare tumor with clinical, radiological and pathologic findings and a review of the literature.
\end{abstract}

Key Words: Congenital, lung tumor, myofibroblastic tumor

Received: 19.12.2012 Accepted: 05.04.2013

\section{Introduction}

Congenital peribronchial myofibroblastic tumor (CPMT) is a rare tumor of childhood that is thought to develop during the early weeks of intrauterine life. It is usually associated with hydrops fetalis and polyhydramnios, and can be detected during prenatal evaluation by ultrasonography. We have found 15 cases in the English-language clinical literature; six of these cases were reported as doing well at 3 months to 6.5 years after resection. In this report, we present the seventh surviving patient, with radiographic, gross, and microscopic features of the tumor, together with a review of the literature.

\section{Case Report}

A 38 year-old female patient, gravida five, para two, abortus one (G5P2A1), at 35 weeks of gestation, was referred to the obstetrics department of our institute with polyhydramnios. She was married to a relative, a maternal cousin. Her first child had died 3 days after birth of unknown causes. Her second and third children are 17 and 15 years old, with no health problems. Her fourth pregnancy was a miscarriage at 21 weeks of gestation. An autopsy performed on this foetus had revealed omphalocele, olygodactyly of the left foot, and flexion deformity of the left hand.

Our case was her fifth pregnancy. Prenatal ultrasonography at 35 weeks revealed polyhydramnios, hydrothorax, and a mass in the right lung. The male neonate was delivered by caesarean section at the $37^{\text {th }}$ gestational week. Birth weight was 3100 gr. The infant was cyanotic, and did not cry at birth; he required intubation and positive-pressure ventilation. Postnatal echocardiography revealed a mass in the right lung, hydrothorax, patent foramen ovale, and pulmonary hypertension. Postnatal computerised tomography showed a solid mass in the right lung, about $6 \mathrm{~cm}$ in diameter (Figure 1). Serum levels of alpha-fetoprotein (AFP) and neuron-specific enolase (NSE) were $15430 \mathrm{ng} / \mathrm{mL}$ (normal: $40-150 \mathrm{ng} / \mathrm{mL}$ ) and $45.02 \mathrm{ng} / \mathrm{mL}$ (normal: $0-16.3 \mathrm{ng} / \mathrm{mL}$ ), respectively.

On day 12 after delivery, the neonate was extubated and was stable after surfactant therapy. A right middle lobectomy was performed by thoracotomy, during which a wellcircumscribed mass, originating from the right middle lobe, was found. Upper and lower lobes were quite normal, and a formal lobectomy was possible without any difficulty. No complications occurred in the postoperative period, and the infant breathed spontaneously. It has been 26 months since the surgery, and the patient is doing well, with no recurrence.

\section{Pathological Findings}

The mass removed at lobectomy was well circumscribed, with no true capsule, and was $6.5 \times 5.5 \mathrm{~cm}$ in size (Figure 2). There was a small area of compressed lung tissue surrounding the mass. Its cut surface was solid and grey-tan, with necrotic areas at the centre.

Microscopically, lung parenchyma was replaced by wellcircumscribed, non-encapsulated mesenchymal tumor (Figure 3). Tumor cells were uniformly spindle-shaped, with finely granular chromatin (Figure 4). There was no anaplasia or pleomorphism. Tumor cells were surrounding the bronchial walls, but not compressing them. Central necrosis was pres- 


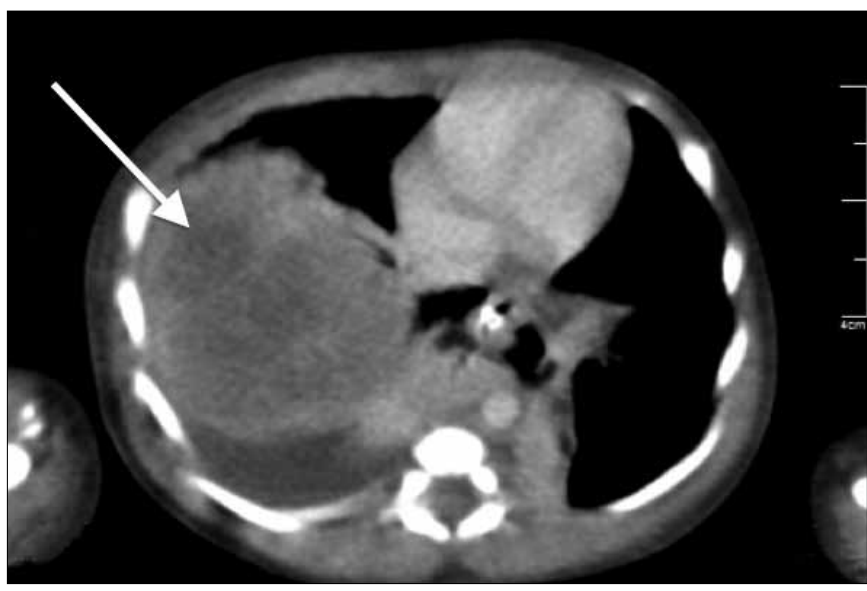

Figure 1. Solid mass replacing in the right lung on Computerised Tomography (CT) (arrow).

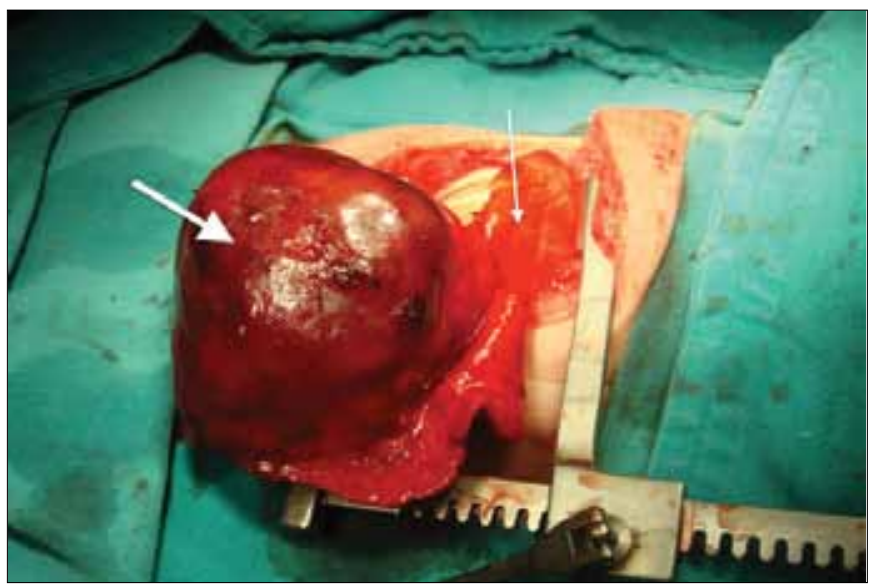

Figure 2. Right middle lobectomy specimen with solid mass (thick arrow) and normal lung parenchyma around the mass (thin arrow).

ent. There were four to five mitoses per ten high power fields (HPF), but no atypical mitoses. There was another small focus of spindle cell proliferation around a bronchioalveolar unit near the tumor, which indicated multifocality (Figure 3).

Immunohistochemically, tumor cells were strongly positive for vimentin. Staining for smooth muscle actin (SMA), desmin, S-100, CD34, human herpesvirus-8 (HHV-8), activin receptorlike kinase-1 (ALK-1), AFP, and NSE were negative.

\section{Discussion}

Congenital peribronchial myofibroblastic tumor is a rare neoplasm of childhood, first described by Jones in 1949 as an unusual hamartoma (1). Morphologically similar tumors were identified as congenital fibrosarcoma, congenital leiomyosarcoma, or congenital mesenchymal malformation until 1993, when McGinnis first used the term CPMT (2). This term was more useful, because of the tumor's favourable outcome, in spite of its morphology. A summary of the English-language reported cases is given in Table 1 (3-14).

Congenital peribronchial myofibroblastic tumor is thought to develop from pluripotent mesenchymal cells,

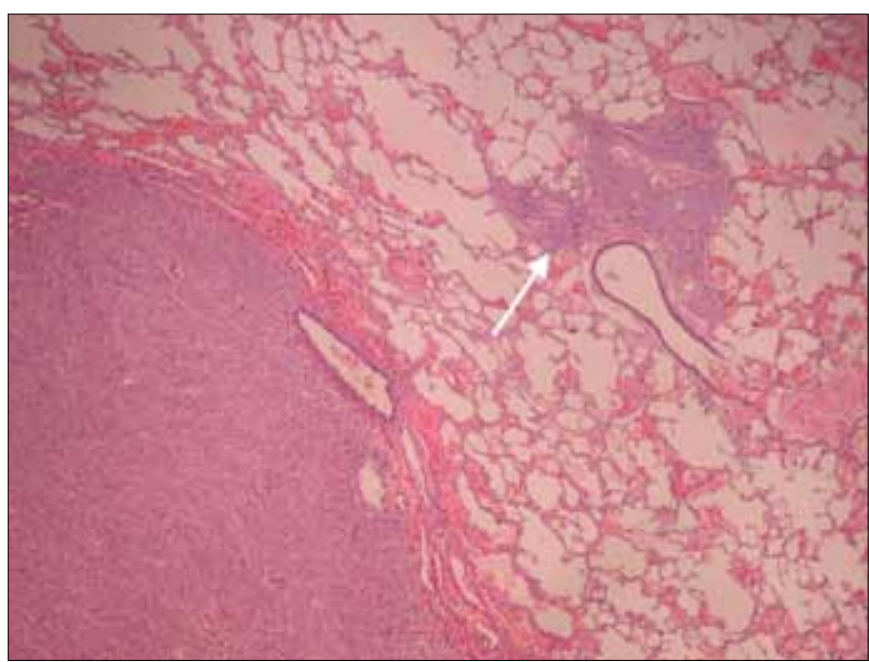

Figure 3. Mesenchymal tumor proliferating around the bronchioles that is replacing but, not compressing the normal lung parenchyma and, another spindle cell proliferation focus near the main tumor (arrow) (H\&E, low power).

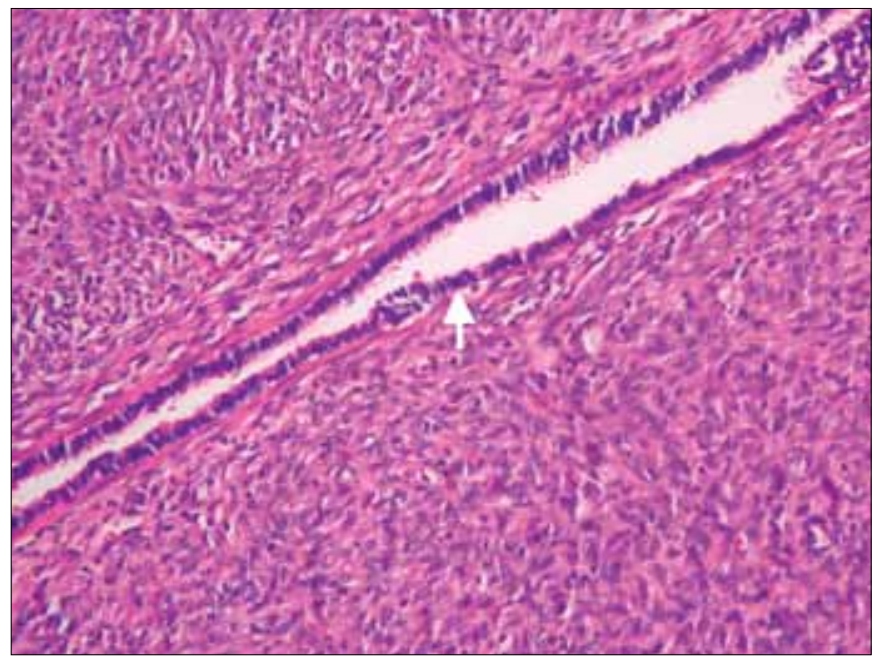

Figure 4. Normal bronchial epithelium can be seen in the tumor (H\&E, high power).

which are destined to differentiate into cartilage or myofibroblasts. Immunohistochemistry and electron microscopy findings support this theory. Immunohistochemically, tumor cells were positive for vimentin in all of the studied cases. Focally, SMA positivity was also reported in three cases (10, $13,14)$, but was negative in others, as in our case. Electron microscopic evaluation suggested a myofibroblastic differentiation. Ultrastructurally, spindle-shaped cells' cytoplasm contained rough endoplasmic reticulum, mitochondria, ribosomes, lysosomes, and a few lipid droplets; some showed bundles of actin filaments (10).

Huppman et al. (13) drew attention to the abundance of mature cartilage in postnatal resection specimens, as compared to a prenatal resection specimen from the same patient in their study. This observation was consistent with their theory that cartilaginous differentiation of the tumor cells was occurring. This was not similar to our case, as we did not see a cartilage component to the tumor. 
Histopathological findings are similar in the literature; i.e., cellular spindled myofibroblastic cells proliferating around the bronchial cartilage. Central necrosis was reported in three cases, all at the centre of the tumors $(10,11,12)$. Thus, this is a coagulation necrosis, rather than a tumor necrosis. Mitotic activity ranged from zero to five mitoses per high power field in the literature (Table 1).

Our case presents an additional finding to those of the previously reported 15 cases. There was an abortus history of a malformed foetus of this mother, 1 year before this birth. Consanguineous marriage of the parents seems to be the most likely reason for the malformations of that foetus, supporting a genetic defect theory in the pathogenesis of
CPMT. Only one report with cytogenetic analysis has been published, which noted a complex rearrangement involving chromosomes 4, 8 and 10, (10) which differed from observations of leiomyosarcoma and fibrosarcoma. Unfortunately, we could not perform chromosomal analyses on any siblings in the present case.

When histopathological and clinical features are considered together, differential diagnosis of a lung mass in children mainly includes hamartoma, inflammatory myofibroblastic tumor, pleuropulmonary blastoma, and congenital fibrosarcoma.

Histologically, hamartomas are usually easy to recognise because of their cartilage, fat, fibrous tissue, bone, and smooth muscle components.

Table 1. The summary of the cases reported in the literature

\begin{tabular}{|c|c|c|c|c|c|c|c|c|c|}
\hline Author & Diagnosis & $\begin{array}{c}\text { Gestational } \\
\text { Age }\end{array}$ & Sex & Outcome & Site & $\begin{array}{c}\text { Cartilaginous } \\
\text { Component }\end{array}$ & Mitosis & Necrosis & is Hydrops \\
\hline Jones (1) & Hamartoma & 28 weeks & $F$ & $\begin{array}{l}\text { Died } 1 \text { hour } \\
\text { after birth }\end{array}$ & RUL & + & N/A & $\mathrm{N} / \mathrm{A}$ & - \\
\hline McGinnis (2) & СРMT & $\begin{array}{c}33 \\
\text { weeks }\end{array}$ & $M$ & $\begin{array}{c}3 \text { days } \\
\text { (intraoperative } \\
\text { death) }\end{array}$ & RUL & + & $\begin{array}{l}\text { Average } \\
1 / 10 \mathrm{HPF}\end{array}$ & $\mathrm{N} / \mathrm{A}$ & $\mathrm{N} / \mathrm{A}$ \\
\hline Robb (3) & $\begin{array}{c}\text { Neonatal } \\
\text { Fibrosarcoma }\end{array}$ & N/A & M & $\begin{array}{l}\text { Well at } 10 \\
\text { months }\end{array}$ & LLL & - & $\begin{array}{c}\text { Present but } \\
\text { not numerous }\end{array}$ & N/A & - \\
\hline Guccion (4) Lei & eiomyosarcoma & N/A & $M$ & $\begin{array}{l}\text { Died shortly } \\
\text { after birth }\end{array}$ & LUL & - & N/A & N/A & N/A \\
\hline Jimenez (5) Lei & eiomyosarcoma & $\begin{array}{c}36 \\
\text { weeks }\end{array}$ & M & $\begin{array}{c}\text { Well at } \\
34 \text { months }\end{array}$ & RLL & - & Occasional & N/A & + \\
\hline \multirow[t]{2}{*}{ Pettinato (6) } & Fibrosarcoma & N/A & M & $\begin{array}{l}\text { Well at } \\
6 \text { years }\end{array}$ & RLL & - & Variable & N/A & $\begin{array}{l}\text { Pleural } \\
\text { effusion }\end{array}$ \\
\hline & & N/A & M & $\begin{array}{l}\text { Well at } \\
3 \text { months }\end{array}$ & LUL & - & & & $\begin{array}{l}\text { Pleural } \\
\text { effusion }\end{array}$ \\
\hline Haller (7) & $\begin{array}{l}\text { Mesenchymal } \\
\text { tumor }\end{array}$ & $\begin{array}{c}40 \\
\text { weeks }\end{array}$ & $\mathrm{F}$ & $\begin{array}{l}\text { Died at } \\
8 \text { hours }\end{array}$ & LLL & - & None & $\mathrm{N} / \mathrm{A}$ & + \\
\hline Warren (8) & $\begin{array}{l}\text { Mesenchymal } \\
\text { malformation }\end{array}$ & $\begin{array}{l}30-33 \\
\text { weeks }\end{array}$ & $F$ & $\begin{array}{c}24 \text { hours } \\
\text { (surgery } \\
\text { complication) }\end{array}$ & LUL/LLL & $\mathrm{N} / \mathrm{A}$ & 1-5/HPF & $\mathrm{N} / \mathrm{A}$ & - \\
\hline Khong (9) & $\begin{array}{l}\text { Mesenchymal } \\
\text { malformation }\end{array}$ & $\begin{array}{c}27 \\
\text { weeks }\end{array}$ & $M$ & At birth & RUL & + & Frequent & N/A & N/A \\
\hline Alobeid (10) & СРMT & $\begin{array}{c}35 \\
\text { weeks }\end{array}$ & $\mathrm{F}$ & $\begin{array}{l}\text { Well at } 1 \\
2 \text { months }\end{array}$ & RML/RLL & $\begin{array}{c}\text { Not } \\
\text { neoplastic }\end{array}$ & 0-3/10 HPF & + & N/A \\
\hline Reiss (11) & СРMT & $\begin{array}{c}25 \\
\text { weeks }\end{array}$ & $M$ & Termination & $\mathrm{L}$ & - & 0-4/10 HPF & + & $\begin{array}{c}\text { Small } \\
\text { pleural effusion }\end{array}$ \\
\hline Horikoshi (12) & СРMT & 30 weeks & M & IUFD & LLL & - & N/A & + & + \\
\hline \multirow[t]{2}{*}{ Huppmann (13) } & СРMT & $\begin{array}{l}23 \text { weeks/ } \\
6 \text { weeks }\end{array}$ & $M$ & $\begin{array}{l}\text { Well at } \\
6.5 \text { years }\end{array}$ & LUL/LLL & + & $\begin{array}{l}\text { Brisk in prenatal } \\
\text { resection }\end{array}$ & - & + \\
\hline & & & & & & & $\begin{array}{l}\text { Occasional in } \\
\text { postnatal resection }\end{array}$ & & \\
\hline de Noronha (14) & 4) $\mathrm{CPMT}$ & $\begin{array}{c}24 \\
\text { weeks }\end{array}$ & $M$ & IUFD & LLL & $\begin{array}{l}\text { Immature } \\
\text { cartilage }\end{array}$ & Frequent & $N / A$ & + \\
\hline Present case & CPMT & $\begin{array}{c}12 \\
\text { days }\end{array}$ & $M$ & $\begin{array}{c}\text { Well at } \\
26 \text { months }\end{array}$ & LML & - & 4-5/10 HPF & + & Hydrothorax \\
\hline
\end{tabular}


Inflammatory myofibroblastic tumors consist of bland spindled and stellate cells with abundant eosinophilic cytoplasm, admixed with scattered inflammatory cells. Immunohistochemically, these myofibroblastic cells are positive for SMA and ALK.

Pleuropulmonary blastoma is a rare malignant embryonic mesenchymal neoplasm, with solid and cystic patterns. The solid pattern may cause difficulty in diagnosis, when it contains fibrosarcoma-like areas. These areas are usually focal, and the rhabdoid appearance of the cells in other tumor areas is a helpful diagnostic finding.

Another quite rare malignant tumor, congenital fibrosarcoma, should also be kept in mind, due to its histological resemblance to CPMT. In fact, some past CPMT cases were identified as congenital fibrosarcoma. Fortunately, this tumor is principally located in the extremities. Histologically, nearly uniform spindle cells are arranged in bundles and fascicles, and mitotic activity varies among different areas of the same tumor. Immunohistochemically, SMA is variably positive.

Fifteen cases may not be enough to reach general conclusions about the features of this tumor, because nine of the patients died either during the intrauterine period or within a short time after surgery, as a result of probable surgical complications (Table 1).

The common findings of the reported cases are that CPMT is a highly cellular mesenchymal tumor, which may appear threatening to the pathologist with its possible necrosis and variable levels of mitosis. The consensus is that all seven surviving patients, including our case, had an excellent outcome after successful surgery. Therefore, it is important to keep this microscopically concerning, but otherwise indolent, lung mass in mind during the evaluation of pregnant women presenting with polyhydramnios due to an intrathoracic mass.

Ethics Committee Approval: This case report was not directly realized on human subject but on human tissue samples archieved in the collection of the Department of Pathology of Medical Faculty in Çukurova University so Ethics Committee Approval was not indicated.

Informed Consent: Written informed consent was obtained from the patient's father.

Peer-review: Externally peer-reviewed.

Author contributions: Concept - A.A., D.G.; Design - A.A., D.G.; Supervision - G.G., D.G.; Resource - A.A., E.B.; Materials - S.i.; Data Collection\&/or Processing - A.A., E.B.; Analysis\&/or Interpretation S.I.; Literature Search - A.A., D.G.; Writing - A.A., S.I.; Critical Reviews - G.G., D.G.

Conflict of Interest: Authors declared no conflict of interest.
Financial Disclosure: Authors don't have any financial disclosure relevant to this study.

\section{References}

1. Jones CJ. Unusual hamartoma of the lung in a newborn infant. Arch Pathol 1949;48:150-4.

2. McGinnis M, Jacobs G, el-Naggar A, Redline RW. Congenital peribronchial myofibroblastic tumor (so-called "congenital leiomyosarcoma"). A distinct neonatal lung lesion associated with nonimmune hydrops fetalis. Mod Pathol 1993;6:487-92.

3. Robb D. A case of neonatal fibrosarcoma of lung. Br J Surg 1958;46:173-4. [CrossRef]

4. Guccion JG, Rosen SH. Bronchopulmonary leiomyosarcoma and fibrosarcoma. A study of 32 cases and review of the literature. Cancer 1972;30:836-47. [CrossRef]

5. Jimenez JF, Uthman EO, Townsend JW, Gloster ES, Seibert JJ. Primary bronchopulmonary leiomyosarcoma in childhood. Arch Pathol Lab Med 1986;110:348-51.

6. Pettinato G, Manivel JC, Saldana MJ, Peyser J, Dehner LP. Primary bronchopulmonary fibrosarcoma of childhood and adolescence: reassessment of a low-grade malignancy. Clinicopathologic study of five cases and review of the literature. Hum Pathol 1989;20:463-71. [CrossRef]

7. Haller JO, Kauffman SL, Kassner EG. Congenital mesenchymal tumour of the lung. Br J Radiol 1977;50:217-9. [CrossRef]

8. Warren JS, Seo IS, Mirkin LD. Massive congenital mesenchymal malformation of the lung: a case report with ultrastructural study. Pediatr Pathol 1985;3:321-8. [CrossRef]

9. Khong TY, Keeling JW. Massive congenital mesenchymal malformation of the lung: another cause of non-immune hydrops. Histopathology 1990;16:609-11. [CrossRef]

10. Alobeid B, Beneck D, Sreekantaiah C, Abbi RK, Slim MS. Congenital pulmonary myofibroblastic tumor: a case report with cytogenetic analysis and review of the literature. Am J Surg Pathol 1997;21:610-4. [CrossRef]

11. Reiss A, Goldberg Y, Monichor M, Drugan A. Congenital pulmonary myofibroblastic tumor--pathology and prenatal sonographic appearance. Prenat Diagn 2005;25:1064-6. [CrossRef]

12. Horikoshi T, Kikuchi A, Matsumoto Y, Tatematsu M, Takae K, Ogiso $Y$, et al. Fetal hydrops associated with congenital pulmonary myofibroblastic tumor. J Obstet Gynaecol Res 2005;31:552-5. [CrossRef]

13. Huppmann AR, Coffin CM, Hoot AC, Kahwash S, Pawel BR. Congenital peribronchial myofibroblastic tumor: comparison of fetal and postnatal morphology. Pediatr Dev Pathol 2011;14:124-9. [CrossRef]

14. de Noronha L, Cecílio WA, da Silva TF, Maggio EM, Serapião MJ. Congenital peribronchial myofibroblastic tumor: a case report. Pediatr Dev Pathol 2010;13:243-6. [CrossRef] 